\title{
Impact of Smoking on Human Natural Killer Cell Activity: A Large Cohort Study
}

\author{
Yoon Suk Jung', Jung Ho Park', Dong II Park', Chong II Sohn', Jae Myun Lee², Tae II Kim³ \\ ${ }^{1}$ Division of Gastroenterology, Department of Internal Medicine, Kangbuk Samsung Hospital, Sungkyunkwan University School of \\ Medicine, ${ }^{2}$ Department of Microbiology and Immunology, Institute for Immunology and Immunological Diseases and Brain Korea \\ 21 PLUS Project for Medical Sciences, Yonsei University College of Medicine, ${ }^{3}$ Department of Internal Medicine and Institute of \\ Gastroenterology, Yonsei Cancer Prevention Center, Brain Korea 21 PLUS Project for Medical Sciences Yonsei University College \\ of Medicine, Seoul, Korea
}

\begin{abstract}
Some studies have reported a decrease in the natural killer (NK) cell activity in smokers. However, large-scale data on the relationship between NK cell activity and smoking are unavailable. A cross-sectional study was performed on 12,249 asymptomatic examinees who underwent an NK cell activity test, between January 2016 and May 2017. The test quantitated the amount of interferon- $\gamma$ secreted into the plasma by NK cells, using a patented stimulatory cytokine. The mean age of the study population was 39.1 years, and the proportions of "never", "former", and "current" smokers were $65.5 \%, 20.9 \%$, and $13.6 \%$, respectively. Current smokers $(1,422$ $\mathrm{pg} / \mathrm{mL})$ had a lower median level of NK cell activity than never smokers $(1,504 \mathrm{pg} / \mathrm{mL}, P=0.039)$ and former smokers $(1,791 \mathrm{pg} /$ $\mathrm{mL}, P<0.001)$. Among current smokers, NK cell activity decreased with increase in the number of cigarettes smoked among current smokers (median, 1,537, 1,429, and $1,175 \mathrm{pg} / \mathrm{mL}$ at $<10,10-19$, and $\geq 20$ pack-years, respectively; $P<0.001$ ). Additionally, it decreased linearly with increasing quartiles of cotinine levels (median, 1,707, 1,636, 1,348, and 1,292 pg/mL at cotinine levels < 292, 292-879, 880-1,509, and $\geq 1,510 \mathrm{ng} / \mathrm{mL}$, respectively; $r=-0.122, P<0.001$ ). NK cell activity was lower in current smokers. It also decreased with an increase in the number of cigarettes smoked, and it was negatively correlated with cotinine levels among current smokers. Our findings indicate a clear relationship between smoking and decreased NK cell activity.
\end{abstract}

Key Words Natural killer cell activity, Smoking, Cotinine

\section{INTRODUCTION}

The host immune system plays a critical role in the surveillance, detection, and elimination of aberrant cells $[1,2]$. Accordingly, the incidences of cancer and infection are increased in immune-compromised hosts [2]. Natural killer (NK) cells are large granular lymphocytes that play an important role in innate immunity, and are involved in the early defense against cancers and infections [1]. Several studies have reported that low NK cell activity is associated with an increased cancer risk, suggesting its role in the natural immunological host defense mechanisms against cancer [3-6].

Cigarette smoke is a major health risk factor which increases the development of many types of cancer [7]. In a murine lung metastasis model, cigarette smoke impaired the NK cell-dependent tumor immune surveillance, and the altered immunity was associated with an increased tumor burden [8]. This study suggests that cigarette smoke compromises host immunity, enabling cancer cells to evade immune responses. Studies on humans have shown that NK cell activity is reduced in smokers [9-15]. Weakened NK cell activity and the consequent altered immune status in smokers may contribute to an increased cancer risk. However, in previously conducted studies which investigated the relationship between NK cell activity and smoking, in humans, the sample size was very low, at around 100 persons [9-15]. Moreover, most of those studies simply compared the NK cell activity between non-smokers and smokers; they did not evaluate NK cell activity, in detail, according to the number of cigarettes smoked.

Established methods that measure NK cell activity, such as the Chromium $51\left({ }^{51} \mathrm{Cr}\right)$ release assay and CD107a degranulation assay, have been widely used to determine

Received February 23, 2020, Revised March 7, 2020, Accepted March 10, 2020

Correspondence to Tae II Kim, E-mail: taeilkim@yuhs.ac, https://orcid.org/0000-0003-4807-890X

Check for updates

(i) (\$) This is an Open Access article distributed under the terms of the Creative Commons Attribution Non-Commercial License, which permits unrestricted noncommercial use, distribution, and reproduction in any medium, provided the original work is properly cited.

Copyright $\odot 2020$ Korean Society of Cancer Prevention 
NK cell function; however, these methods are complicated and time-consuming, because they require the isolation of the peripheral blood mononuclear cells (PBMC) or NK cells [16]. In addition, these assays sometimes require the use of hazardous materials such as radioactive isotopes [16]. Because of these difficulties in measuring NK cell activity, large-scale data on the relationship between NK cell activity and smoking in humans are currently unavailable.

To overcome these difficulties, a simple assay that uses whole blood instead of PBMC or isolated NK cells was recently developed for commercial use, to measure the activity of NK cells (NK Vue ${ }^{\circledR}$ Kit; ATGen, Seongnam, Korea) $[4,17]$. This novel assay employs the serum of ex vivo stimulated whole blood to detect the IFN-y secreted from the NK cells as an indicator of NK cell activity $[4,17]$. We aimed to evaluate the association of NK cell activity with the number of cigarettes smoked as well as smoking status, in a very large sample of asymptomatic examinees, using this novel and simple blood test. We also evaluated the relationship between NK cell activity and urinary cotinine level, an objective biomarker for tobacco exposure, to more clearly identify the association between NK cell activity and smoking.

\section{MATERIALS AND METHODS}

\section{Study population}

The Kangbuk Samsung Health Study is a cohort study of South Korean men and women, aged 18 years or older, who underwent a comprehensive annual or biennial health examination at the Kangbuk Samsung Hospital Total Healthcare Center in Seoul and Suwon, South Korea. The study population consisted of a subset of Kangbuk Samsung Health Study participants who underwent the NK cell activity test from January 2016 to May 2017. In South Korea, the Industrial Safety and Health Law requires annual or biennial health screening examinations of all employees, which are offered free of charge. Approximately $80 \%$ of the participants were employees of various companies and local governmental organizations, or their spouses, and the remaining participants volunteered for the screening examinations.

The exclusion criteria included having a history of cancer, inflammatory bowel disease, autoimmune disorders, known hepatitis $\mathrm{B}$ or $\mathrm{C}$ infections, and/or prescription use of immunosuppressive drugs, corticosteroids, and antibiotics within the last one month. Participants with missing data on smoking status were also excluded.

This study was approved by the Institutional Review Board (IRB) of Kangbuk Samsung Hospital, which exempted the requirement for informed consent because only de-identified data were accessed, retrospectively (IRB number: KBSMC 2017-06-007). All methods were performed in accordance with the relevant guidelines and regulations.

\section{Measurement and definition of variables}

Data on smoking status and comorbidities were collected through a self-administered questionnaire. Smoking habits were defined using the criteria of the National Health Interview Survey [18]. Participants who have smoked $\geq$ 100 cigarettes in their life and continued smoking cigarettes were defined as "current smokers". If the participants have smoked $\geq 100$ cigarettes in their life, but did not smoke any longer, they were defined as "former smokers". Participants who have never smoked a cigarette or have smoked $<100$ cigarettes in their life were defined as "never smokers". The self-reported use of medication, on a regular basis over the last month, was also assessed. Obesity was defined as a body mass index $\geq 30 \mathrm{~kg} / \mathrm{m}^{2}$, based on the criteria of the World Health Organization [19].

Urinary cotinine levels were determined using the DRI Cotinine Assay (Microgenics Corp., Fremont, CA, USA) with the modular P800 analyzer (Roche Diagnostics, Tokyo, Japan). Cotinine-verified smokers were defined as participants having a urinary cotinine level $\geq 50 \mathrm{ng} / \mathrm{mL}$ [20].

The presence or absence of fatty liver was examined through abdominal ultrasonography (US). A US diagnosis of fatty liver was made on the basis of four known criteria, namely: hepatorenal echogenic contrast, liver brightness, deep attenuation, and vascular blurring [21]. In our study, abdominal US was performed using a $3.5-\mathrm{MHz}$ transducer (Logiq 9; General Electric, Madison, WI, USA), by experienced radiologists.

\section{Natural killer cell activity measurement}

NK cell activity was measured using a recently developed simple blood test (NK Vue ${ }^{\circledR}$ kit; ATGen). A 1-mL sample of whole blood, drawn using a direct vacutainer system from a new venipuncture point, was directly transferred into a tube specific to the NK cell activity test. The blood collection tube for the NK cell activity test contains a patented stimulatory cytokine (Promoca ${ }^{\mathrm{TM}}$; ATGen). The collected tube was gently and repeatedly mixed. Within 30 minutes of collection, it was incubated for $20-24$ hours in a $37^{\circ} \mathrm{C}$ chamber, according to the manufacturer's recommendation. During the incubation period, the stimulatory cytokine causes the secretion of IFN- $\gamma$ into the plasma, predominantly by the NK cells, rather than by other innate or adaptive immune cells [17].

Following incubation, the supernatant was collected and centrifuged at $3,000 \times g$ for 3 minutes. The supernatant was immediately loaded onto the ELISA plates. The IFN- $\gamma$ was quantitated with a designed ELISA, and the level of IFN- $\gamma$ was expressed in $\mathrm{pg} / \mathrm{mL}$.

Although the concentration of IFN- $\gamma$ indicates NK cell activity, it is difficult to assume that it is exactly the same as NK cell activity. However, we expressed the concentration of IFN- $\gamma$ as NK cell activity for convenience. 


\section{Statistical analysis}

Continuous variables were described as mean \pm SD or median (interquartile range, IQR), and categorical variables were presented as frequencies and percentages. Baseline characteristics according to the smoking status were compared using one-way analysis of variance and chi-square test for continuous and categorical variables, respectively. The comparison of the NK cell activity levels, according to the clinical characteristics including smoking habits, was performed using the non-parametric Mann-Whitney U-test or Kruskal-Wallis test. Among current smokers, the comparison of the proportion of participants with low vs. high NK cell activity levels ( $<500 \mathrm{pg} / \mathrm{mL}$ vs. $\geq 500 \mathrm{pg} / \mathrm{mL}$ ), according to the number of cigarettes smoked and duration of smoking, was performed using univariable logistic regression analysis. Age and sex were adjusted using the multivariable logistic regression model. The association between NK cell activity level and urinary cotinine level was assessed using Spearman's rank correlation coefficients $(r)$ for nonparametric correlations. All reported $P$-values were two-tailed, and $P$-values $<0.05$ were considered statistically significant. PASW Statistics ver. 18 software (IBM Corp., Armonk, NY, USA) was used for statistical analyses.

\section{RESULTS}

Baseline characteristics of the study population We reviewed the medical records of 13,595 participants who had undergone the NK cell activity test. Of these, 972 were excluded because of a history of cancer $(n=$ $488)$, inflammatory bowel disease $(n=68)$, autoimmune disorders (systemic lupus erythematosus, $n=6$ ), hepatitis B infection $(n=394)$, and/or hepatitis C infection ( $n=16)$. Additionally, 356 participants were excluded due to the use of immunosuppressive drugs $(n=25)$, corticosteroids $(n=28)$, and antibiotics $(n=303)$ within the last month. After excluding 18 participants with missing data on smoking habits, 12,249 participants were finally analyzed.

The baseline clinical characteristics of the study population are shown in Table 1. The mean age of the study population was $39.1 \pm 7.7$ years, and the proportion of males was $60.2 \%$. The proportions of never smokers, former smokers, and current smokers were $65.5 \%(n=8,028), 20.9 \%$ ( $n$ $=2,560)$, and $13.6 \%(n=1,661)$, respectively, and the proportion of cotinine-verified smokers (cotinine $\geq 50 \mathrm{ng} / \mathrm{mL}$ ) was $12.4 \%(n=1,301)$. The mean age and the proportion of males, as well as the prevalence of obesity, hypertension, diabetes mellitus, dyslipidemia, and fatty liver were higher in former or current smokers than in never smokers. The proportions of cotinine-verified smokers (cotinine $\geq 50 \mathrm{ng} / \mathrm{mL}$ ) among never, former, and current smokers were $0.6 \%, 5.0 \%$, and $85.8 \%$, respectively.

\section{Natural killer cell activity according to smoking status and clinical characteristics}

The median level of NK cell activity (level of IFN- $\gamma$ ) of all the participants was 1,546 pg/mL (IQR, 673-2,722 pg/mL). Table 2 shows the median levels of NK cell activity, according to the clinical characteristics including smoking habits. Current smokers had lower NK cell activity than never smokers $(1,422$ vs. $1,504 \mathrm{pg} / \mathrm{mL}, P=0.039)$. Current smokers also had lower NK cell activity than former smokers $(1,422$ vs. $1,791 \mathrm{pg} / \mathrm{mL}$, $P<0.001)$. However, former smokers had a rather higher level of NK cell activity than never smokers (1,791 vs. 1,504 $\mathrm{pg} / \mathrm{mL}, P<0.001$ ). Cotinine-verified smokers (cotinine $\geq 50$ $\mathrm{ng} / \mathrm{mL}$ ) had lower NK cell activity than cotinine-verified nonsmokers (cotinine $<50 \mathrm{ng} / \mathrm{mL})(1,434$ vs. $1,623 \mathrm{pg} / \mathrm{mL}, P<$ 0.001).

The median level of NK cell activity was significantly lower in participants aged $\geq 40$ years than in those aged $<40$ years $(1,483$ vs. $1,602 \mathrm{pg} / \mathrm{mL}, P<0.001)$, and it was also lower in females than in males $(1,318$ vs. $1,724 \mathrm{pg} / \mathrm{mL}, P<$ $0.001)$. There was no significant difference in the levels of NK cell activity between participants with and without obesity,

Table 1. Baseline characteristics according to the smoking status

\begin{tabular}{|c|c|c|c|c|c|}
\hline Baseline characteristic & $\begin{array}{c}\text { Total } \\
(\mathrm{n}=12,249)\end{array}$ & $\begin{array}{l}\text { Never smokers } \\
\quad(n=8,028)\end{array}$ & $\begin{array}{l}\text { Former smokers } \\
\qquad(n=2,560)\end{array}$ & $\begin{array}{l}\text { Current smokers } \\
\quad(n=1,661)\end{array}$ & $P$-value \\
\hline Age (yr) & $39.1 \pm 7.7$ & $37.8 \pm 7.5$ & $41.6 \pm 7.7$ & $41.2 \pm 7.4$ & $<0.001$ \\
\hline Male & $7,371(60.2)$ & $3,337(41.6)$ & $2,431(95.0)$ & $1,603(96.5)$ & $<0.001$ \\
\hline Obesity $\left(\mathrm{BMI} \geq 30 \mathrm{~kg} / \mathrm{m}^{2}\right)$ & $468(3.8)$ & $268(3.3)$ & $99(3.9)$ & $101(6.1)$ & $<0.001$ \\
\hline Hypertension & $882(7.2)$ & $383(4.8)$ & $329(12.9)$ & $170(10.2)$ & $<0.001$ \\
\hline Diabetes mellitus & $300(2.4)$ & $105(1.3)$ & $105(4.1)$ & $90(5.4)$ & $<0.001$ \\
\hline Dyslipidemia & $1,907(15.6)$ & $889(11.1)$ & $612(23.9)$ & $406(24.4)$ & $<0.001$ \\
\hline Fatty liver & $3,691(30.1)$ & $1,845(23.0)$ & $1,113(43.5)$ & $734(44.2)$ & $<0.001$ \\
\hline \multicolumn{6}{|l|}{ Urinary cotinine $(\mathrm{ng} / \mathrm{mL})^{a}$} \\
\hline$<50$ & $9,201(87.6)$ & $6,960(99.4)$ & $2,051(95.0)$ & $190(14.2)$ & $<0.001$ \\
\hline$\geq 50$ & $1,301(12.4)$ & $45(0.6)$ & $108(5.0)$ & $1,148(85.8)$ & \\
\hline
\end{tabular}

Values are presented as mean \pm SD or number (\%). Baseline characteristics between groups were compared using one-way analysis of variance and chi-square test for continuous and categorical variables, respectively. BMI, body mass index. ${ }^{\mathrm{a}}$ There are missing values in 1,747 individuals. 
Table 2. Levels of NK cell activity according to the clinical characteristics

\begin{tabular}{|c|c|c|}
\hline Clinical characteristic & $\begin{array}{l}\text { NK cell activity } \\
\quad(\mathrm{pg} / \mathrm{mL})\end{array}$ & $P$-value \\
\hline \multicolumn{3}{|l|}{ Smoking status ( 3 categories) } \\
\hline Never smoker & $1,504(656-2,697)$ & $<0.001$ \\
\hline Former smokers & $1,791(802-2,856)$ & \\
\hline Current smokers & $1,422(623-2,592)$ & \\
\hline \multicolumn{3}{|l|}{ Smoking status ( 2 categories) } \\
\hline Never or former smokers & $1,572(685-2,741)$ & 0.001 \\
\hline Current smokers & $1,422(623-2,592)$ & \\
\hline \multicolumn{3}{|l|}{ Urinary cotinine $\mathrm{a}^{\mathrm{a}}$} \\
\hline$<50 \mathrm{ng} / \mathrm{mL}$ & $1,623(716-2,802)$ & $<0.001$ \\
\hline$\geq 50 \mathrm{ng} / \mathrm{mL}$ & $1,434(644-2,647)$ & \\
\hline \multicolumn{3}{|l|}{ Age $(y r)$} \\
\hline$<40(n=6,797)$ & $1,602(706-2,776)$ & $<0.001$ \\
\hline$\geq 40(n=5,452)$ & $1,483(640-2,656)$ & \\
\hline \multicolumn{3}{|l|}{ Sex } \\
\hline Male & $1,724(761-2,815)$ & $<0.001$ \\
\hline Female & $1,318(577-2,514)$ & \\
\hline \multicolumn{3}{|l|}{ Obesity } \\
\hline No $\left(\mathrm{BMI}<30 \mathrm{~kg} / \mathrm{m}^{2}\right)$ & $1,553(678-2,724)$ & 0.213 \\
\hline Yes $\left(\mathrm{BMI} \geq 30 \mathrm{~kg} / \mathrm{m}^{2}\right)$ & $1,423(600-2,680)$ & \\
\hline \multicolumn{3}{|l|}{ Hypertension } \\
\hline No & $1,546(674-2,725)$ & 0.663 \\
\hline Yes & $1,536(658-2,692)$ & \\
\hline \multicolumn{3}{|l|}{ Diabetes mellitus } \\
\hline No & $1,552(675-2,724)$ & 0.168 \\
\hline Yes & $1,413(603-2,631)$ & \\
\hline \multicolumn{3}{|l|}{ Dyslipidemia } \\
\hline No & $1,542(672-2,720)$ & 0.625 \\
\hline Yes & $1,575(680-2,735)$ & \\
\hline \multicolumn{3}{|l|}{ Fatty liver } \\
\hline No & $1,531(661-2,717)$ & 0.172 \\
\hline Yes & $1,572(706-2,733)$ & \\
\hline
\end{tabular}

Values are presented as median (interquartile range). The levels of NK cell activity were compared using the non-parametric Mann-Whitney U-test or Kruskal-Wallis test. NK, natural killer; $\mathrm{BMI}$, body mass index. ${ }^{\text {a }}$ There are missing values in 1,747 individuals.

hypertension, diabetes mellitus, dyslipidemia, and fatty liver.

\section{Association between natural killer cell activity and the number of cigarettes smoked among current smokers}

To determine whether the number of cigarettes smoked influences NK cell activity, we compared the levels of NK cell activity, according to the number of cigarettes smoked and duration of smoking, among current smokers. Table 3 shows that the median level of NK cell activity significantly decreased with increases in the number of cigarettes smoked and duration of cigarette smoking, among current smokers. Current smokers who smoked 20 or more cigarettes per day (median, 1,184 pg/mL; IQR, 487-2,064 pg/mL) had a lower NK cell activity than those who smoked 10-19 cigarettes per day (median, 1,468 pg/mL; IQR, 629-2,666 pg/mL; $P<$
Table 3. Levels of NK cell activity according to the number of cigarettes smoked and duration of smoking, among current smokers

\begin{tabular}{|c|c|c|}
\hline Smoking status & $\begin{array}{l}\text { NK cell activity } \\
(\mathrm{pg} / \mathrm{mL})\end{array}$ & $P$-value \\
\hline \multicolumn{3}{|l|}{ Daily number of cigarettes smoked } \\
\hline$<10$ cigarettes/day $(n=457)$ & $1,522(728-2,734)$ & $<0.001$ \\
\hline $10-19$ cigarettes/day $(n=874)$ & $1,468(629-2,666)$ & \\
\hline$\geq 20$ cigarettes/day $(n=330)$ & $1,184(487-2,064)$ & \\
\hline \multicolumn{3}{|l|}{ Duration of cigarette smoking } \\
\hline$<20$ years $(n=685)$ & $1,514(686-2,625)$ & 0.040 \\
\hline$\geq 20$ years $(n=976)$ & $1,334(567-2,575)$ & \\
\hline \multicolumn{3}{|c|}{ Total number of cigarettes smoked } \\
\hline$<10$ pack-years $(\mathrm{n}=738)$ & $1,537(706-2,699)$ & $<0.001$ \\
\hline 10-19 pack-years $(n=612)$ & $1,429(560-2,664)$ & \\
\hline$\geq 20$ pack-years $(n=311)$ & $1,175(534-2,109)$ & \\
\hline \multicolumn{3}{|l|}{ Urinary cotinine $^{a}$} \\
\hline$<50 \mathrm{ng} / \mathrm{mL}(\mathrm{n}=190)$ & $1,906(857-2,875)$ & 0.001 \\
\hline$\geq 50 \mathrm{ng} / \mathrm{mL}(\mathrm{n}=1,148)$ & $1,423(629-2,601)$ & \\
\hline \multicolumn{3}{|l|}{ Urinary cotinine $^{b}$} \\
\hline$<292 \mathrm{ng} / \mathrm{mL}(\mathrm{n}=332)$ & $1,707(840-2,865)$ & $<0.001$ \\
\hline $292-879 \mathrm{ng} / \mathrm{mL}(\mathrm{n}=337)$ & $1,636(690-2,811)$ & \\
\hline $880-1,509 \mathrm{ng} / \mathrm{mL}(\mathrm{n}=334)$ & $1,348(590-2,593)$ & \\
\hline$\geq 1,510 \mathrm{ng} / \mathrm{mL}(\mathrm{n}=335)$ & $1,292(534-2,235)$ & \\
\hline
\end{tabular}

Values are presented as median (interquartile range). The levels of NK cell activity were compared using the non-parametric MannWhitney U-test or Kruskal-Wallis test. NK, natural killer. ${ }^{\text {aThere }}$ are missing values in 323 individuals. ${ }^{b}$ Values were categorized into four groups by the quartiles of urinary cotinine levels.

0.001 ), as well as those who smoked less than 10 cigarettes per day (median, 1,522 pg/mL; IQR, 728-2,734 pg/mL; $P<$ 0.001 ) (Fig. 1A). In addition, current smokers who had been smoking for 20 or more years had lower NK cell activity than those had been smoking for less than 20 years (median, 1,334 vs. $1,514 \mathrm{pg} / \mathrm{mL}, P=0.040$ ). Current smokers with $\geq$ 20 pack-years (median, 1,175 pg/mL; IQR, 534-2,109 pg/mL) had lower NK cell activity than those with 10-19 pack-years (median, 1,429 pg/mL; IQR, 560-2,664 pg/mL; $P=0.023$ ), as well as those with $<10$ pack-years (median, $1,537 \mathrm{pg} / \mathrm{mL}$; IQR, 706-2,699 pg/mL; $P<0.001$ ). Current smokers, with 1019 pack-years, also had lower NK cell activity than those with $<10$ pack-years $(P=0.039)$ (Fig. $1 \mathrm{~B})$.

The manufacturer (ATGen) has set four intervals: low, borderline, concerned, and normal section, and presented the values of the percentiles $2.5 \%$ (100 pg/mL), 10\% (250 $\mathrm{pg} / \mathrm{mL})$, and $20 \%(500 \mathrm{pg} / \mathrm{mL})$ as the cut-off values among these four intervals. In our cohort, the NK cell activity level at the 20th percentile was " $540 \mathrm{pg} / \mathrm{mL}$ " and accordingly, we compared the number of cigarettes smoked and duration of smoking based on "500 pg/mL", for convenience (Table 4). Among current smokers, those who smoked 10-19 cigarettes per day, as well as those who smoked 20 or more cigarettes per day, had lower NK cell activity level $(<500 \mathrm{pg} / \mathrm{mL})$, compared to those who smoked less than 10 cigarettes per day $(\mathrm{OR}, 1.61 ; 95 \% \mathrm{Cl}, 1.14-2.27 ; P=0.007$ and $1.41 ; 1.04-$ 
A

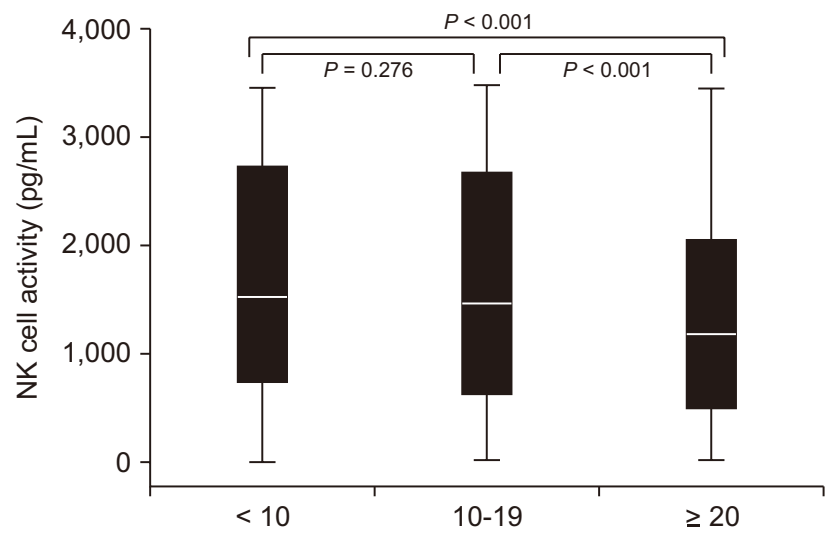

B

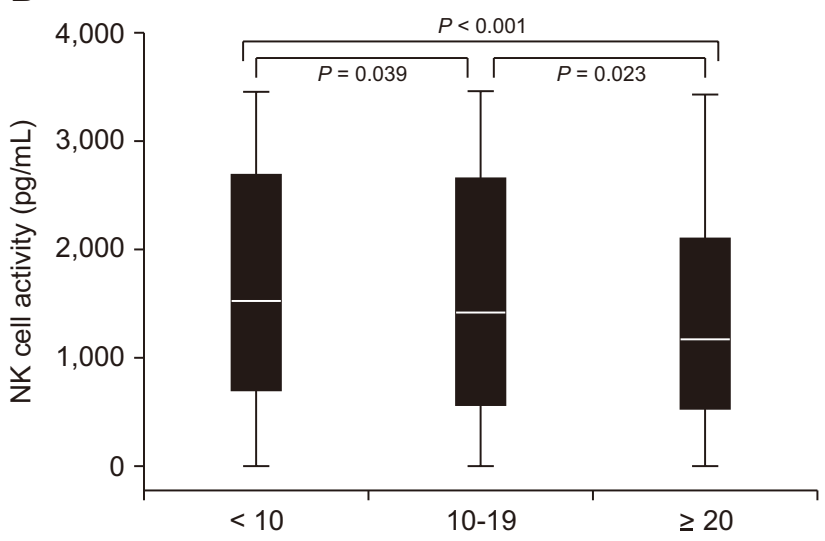

Total amount of cigarette smoke (pack-years)

Figure 1. Comparison of natural killer (NK) cell activity, according to the number of cigarettes smoked, among current smokers. (A) NK cell activity decreased with increases in the daily number of cigarettes smoked. (B) NK cell activity decreased with increases in the pack-years. The levels of NK cell activity between groups were compared using Mann-Whitney U-test.

Table 4. Association of NK cell activity with the number of cigarettes smoked and duration of smoking, among current smokers

\begin{tabular}{|c|c|c|c|c|c|c|}
\hline \multirow[b]{2}{*}{ Smoking status } & \multicolumn{2}{|c|}{ NK cell activity } & \multirow{2}{*}{$\begin{array}{l}\text { Univariable } \\
\text { analysis }\end{array}$} & \multirow[b]{2}{*}{$P$-value } & \multirow{2}{*}{$\begin{array}{l}\text { Multivariable } \\
\text { analysis }^{\text {b }}\end{array}$} & \multirow[b]{2}{*}{$P$-value } \\
\hline & $\begin{array}{c}<500 \mathrm{pg} / \mathrm{mL} \\
(n=339)\end{array}$ & $\begin{array}{c}\geq 500 \mathrm{pg} / \mathrm{mL} \\
(\mathrm{n}=1,322)\end{array}$ & & & & \\
\hline \multicolumn{7}{|c|}{ Daily number of cigarettes smoked } \\
\hline$<10$ cigarettes/d & $81(17.7)$ & $376(82.3)$ & 1 & & 1 & \\
\hline $10-19$ cigarettes/d & $173(19.8)$ & $701(80.2)$ & $1.61(1.14-2.27)$ & 0.007 & $1.67(1.17-2.39)$ & 0.005 \\
\hline$\geq 20$ cigarettes $/ \mathrm{d}$ & $85(25.8)$ & $245(74.2)$ & $1.41(1.04-1.89)$ & 0.025 & $1.36(1.005-1.84)$ & 0.046 \\
\hline \multicolumn{7}{|c|}{ Duration of cigarette smoking } \\
\hline$<20 \mathrm{yr}$ & $124(18.1)$ & $561(81.9)$ & 1 & & 1 & \\
\hline$\geq 20 \mathrm{yr}$ & $215(22.0)$ & $761(78.0)$ & $1.28(0.999-1.64)$ & 0.051 & $1.11(0.80-1.54)$ & 0.522 \\
\hline \multicolumn{7}{|c|}{ Total number of cigarettes smoked } \\
\hline$<10$ pack-years & $126(17.1)$ & $612(82.9)$ & 1 & & 1 & \\
\hline$\geq 10$ pack-years & $213(23.1)$ & $710(76.9)$ & $1.46(1.14-1.86)$ & 0.003 & $1.45(1.10-1.92)$ & 0.008 \\
\hline \multicolumn{7}{|l|}{ Urinary cotinine $e^{a}$} \\
\hline$<50 \mathrm{ng} / \mathrm{mL}$ & $28(14.7)$ & $162(85.3)$ & 1 & & 1 & \\
\hline$\geq 50 \mathrm{ng} / \mathrm{mL}$ & $242(21.1)$ & $906(79.8)$ & $1.55(1.01-2.37)$ & 0.045 & $1.53(0.998-2.34)$ & 0.051 \\
\hline
\end{tabular}

Values are presented as number $(\%)$ or OR $(95 \% \mathrm{CI})$. NK, natural killer. ${ }^{a}$ There are missing values in 323 individuals. ${ }^{b}$ Values were adjusted for age and sex.

1.89; $P=0.025$, respectively). In addition, current smokers with $\geq 10$ pack-years had lower NK cell activity level $(<500$ $\mathrm{pg} / \mathrm{mL}$ ) than those with < 10 pack-years (OR, 1.46; 95\% $\mathrm{Cl}, 1.14-1.86 ; P=0.003)$. After adjusting for age and sex, that showed a significant difference in NK cell activity, the associations between smoking amount (both daily and total) and NK cell activity remained significant.

\section{Association between natural killer cell activity and urinary cotinine levels among current smokers}

Current smokers with urinary cotinine levels $\geq 50 \mathrm{ng} / \mathrm{mL}$ had lower NK cell activity than those with urinary cotinine levels $<50 \mathrm{ng} / \mathrm{mL}$ (median, 1,423 vs. 1,906, $P=0.001$ ). To identify the association between NK cell activity and urinary cotinine levels more clearly, the levels of NK cell activity were compared between four groups, by quartiles of urinary cotinine levels. The median levels of NK cell activity decreased linearly with increasing quartiles of urinary cotinine levels $(1,707,1,636,1,348$, and $1,292 \mathrm{pg} / \mathrm{mL}$ in current smokers, with urinary cotinine levels $<292$, 292-879, 8801,509 , and $\geq 1,510 \mathrm{ng} / \mathrm{mL}$, respectively; $P<0.001$ ) (Table 3). Figure 2 shows a significant negative correlation between the NK cell activity levels and quartiles of urinary cotinine levels $(r=-0.122, P<0.001)$. Urinary cotinine levels by themselves were also negatively correlated with NK cell activity $(r=$ $-0.137, P<0.001)$. 


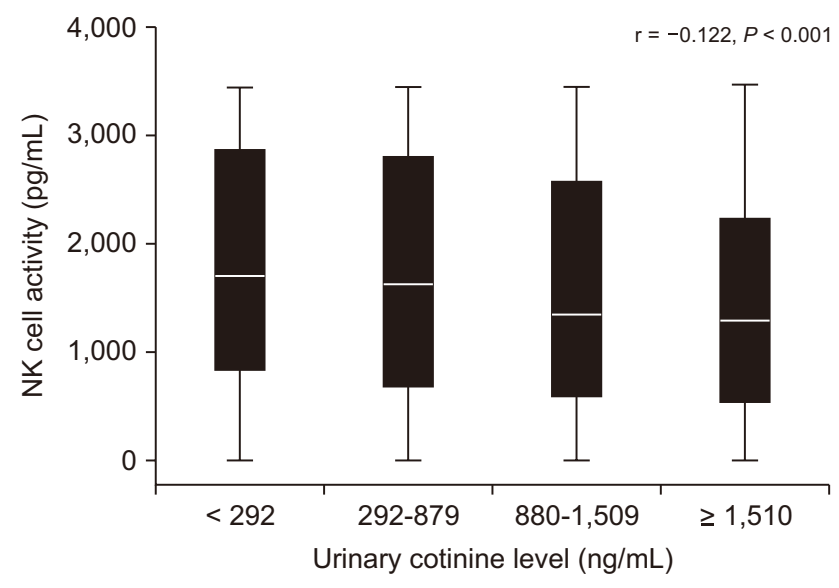

Figure 2. Correlation between natural killer (NK) cell activity levels and urinary cotinine levels. The correlation was assessed using Spearman's rank correlation coefficients.

\section{DISCUSSION}

In this large-scale study, including 12,249 asymptomatic participants, we found that current smokers had lower NK cell activity than never smokers and former smokers. Additionally, among current smokers, the level of NK cell activity decreased with increases in the number of cigarettes smoked, even after adjusting for age and sex. In addition, it was also negatively correlated with urinary cotinine levels.

Some animal studies have shown a decrease in NK cell activity under conditions of cigarette smoke exposure [8,22]. Spleen cells from animals subjected to a heavy dose of cigarette smoke exhibited a significant reduction in the NK cell-mediated lytic activity [22]. Another study revealed that cigarette smoke impairs NK cell-mediated tumor immune surveillance, and that altered immunity is associated with increased lung tumor burden in mice [8]. Several studies on humans have also reported that NK cell activity is more reduced in smokers than non-smokers [9-15,23]. However, a limitation of those previously conducted studies on humans is the very small sample size. With the exception of one study [23], the number of samples in all those studies ranged from 54-119 participants [9-15].

Several assays are available for the measurement of NK cell activity. Since 1968, the gold standard in the assessment of NK cell activity has been the ${ }^{51} \mathrm{Cr}$ release assay, which is used to determine the cytolytic activity of effector cell populations [16]. However, the ${ }^{51} \mathrm{Cr}$ release assay has many limitations, such as hazardous radioactivity, high cost, and short half-life of the isotopes [16]. Other established methods to assess NK cell activity, such as the CD107a degranulation assay and intracellular staining of IFN- $\gamma$ produced in NK cells, require the isolation of PBMC or NK cells from whole blood $[24,25]$. Furthermore, they require large amounts of whole blood to obtain enough PBMC or NK cells $[24,25]$. Due to the associated inconvenience and complexity, these methods have been used in research settings only. Accordingly, largescale data on the association between NK cell activity and smoking in humans are currently unavailable.

Using a simplified assay that uses whole blood, without the need to isolate of PBMC or NK cells, we could measure NK cell activity in a large sample of examinees. Like in the case of previously conducted studies' results, our study showed that the NK cell activity was lower in current smokers than in never or former smokers. In addition, we found that NK cell activity decreased with increases in the number of cigarettes smoked, in a dose-response manner, among current smokers. Contrary to our study, most previously conducted studies simply compared NK cell activity between smokers and non-smokers. Our study is the first to evaluate NK cell activity, in detail, according to the number of cigarettes smoked. The higher degree of weakened NK cell activity and, consequently, altered immune status, may contribute to a higher risk of cancer in heavy smokers than light smokers.

In the present study, cotinine-verified smoking (cotinine $\geq$ $50 \mathrm{ng} / \mathrm{mL}$ ) was also associated with reduced NK cell activity. Participants with cotinine levels $\geq 50 \mathrm{ng} / \mathrm{mL}$ had lower NK cell activity than those with cotinine levels $<50 \mathrm{ng} / \mathrm{mL}$, even among current smokers. Furthermore, NK cell activity was negatively correlated with cotinine levels. Given that cotinine is an objective biomarker for tobacco exposure, our results provide obvious evidence on the effect of smoking on NK cell activity.

Interestingly, former smokers had a rather higher level of NK cell activity than never smokers. One of the reasons may be that former smokers may have healthier lifestyles after quitting smoking. Our results are in accordance with those of an experimental study which showed that smoking cessation completely reversed the detrimental effects of cigarette smoke on tumor immune surveillance; this suggests that the impact of cigarette smoke on the NK cells is reversible [8]. Based on that study's results and our own, smoking cessation may restore tumor immune surveillance. Our findings suggest that smoking cessation can reduce the risk of the development of smoking-related diseases.

We assessed NK cell activity according to other clinical characteristics, in addition to smoking status. NK cell activity was not different, depending on the presence of comorbidities including obesity, hypertension, diabetes mellitus, dyslipidemia, and fatty liver, whereas it was lower in older participants ( $\geq 40$ years) than those aged $<40$ years, and it was also lower in women than in men. Like in the case of our results, a previously conducted study showed that older participants had lower NK cell activity than younger participants [26], and a recent study also pointed to an age-related reduction in NK cell activity [27]. Another study reported that NK cell activity was greater in men than in women [28]. NK cell activity may vary by age and sex. Further studies are needed to clarify if age and sex should be considered when determining the cut-off value of the NK cell 
activity test, for the detection of certain cancers.

To our knowledge, this is the largest study to identify the association between human NK cell activity and smoking. In addition, our study is the first to show a negative correlation between NK cell activity and cotinine. Nevertheless, the current study has several limitations. First, our study was not population-based, and included only ethnic Koreans. The interpretation of our findings requires careful consideration when applied to other populations. Second, most of the participants were employees of various companies and local governmental organizations, or their spouses; hence, there was a potential selection bias because most of them were likely to have a middle or upper class socio-economic status. Third, since most of the current smokers $(96.5 \%)$ were men, the evaluation of the impact of smoking on NK cell activity in women was limited. Fourth, lifestyle factors such as mental stress and exercise, which may affect the levels of NK cell activity, were not considered. Fifth, the cross-sectional design precludes the determination of causality. In this study, longitudinal data were not collected, and hence we could not assess the changes of NK cell activities according to smoking status (such as smoking cessation). To more clearly elucidate the impact of smoking on NK cell activity, further longitudinal studies should be conducted. Finally, potential limitations of our study include its retrospective nature without measuring other cytokines, and we did not elaborate on the mechanism by which smoking affects NK cell activity.

Despite these limitations, our data provide a better understanding of the effect of smoking on human NK cell activity. NK cell activity was lower in current smokers than in former or never smokers. It also decreased with increases in the number of cigarettes smoked, in a dose-response manner, among current smokers. Furthermore, it was negatively correlated with urinary cotinine levels. Our findings indicate a clear relationship between smoking and decreased NK cell activity.

\section{CONFLICTS OF INTEREST}

No potential conflicts of interest were disclosed.

\section{ORCID}

Yoon Suk Jung, https://orcid.org/0000-0002-1963-7170

Jung Ho Park, https://orcid.org/0000-0002-8367-4371

Dong II Park, https://orcid.org/0000-0003-2307-8575

Chong II Sohn, https://orcid.org/0000-0002-9748-8537

Jae Myun Lee, https://orcid.org/0000-0002-5273-3113

Tae II Kim, https://orcid.org/0000-0003-4807-890X

\section{REFERENCES}

1. Bryceson $Y T$, Chiang SC, Darmanin S, Fauriat $C$, Schlums $H$, Theorell $\mathrm{J}$, et al. Molecular mechanisms of natural killer cell activation. J Innate Immun 2011;3:216-26.

2. Kim S, lizuka K, Aguila HL, Weissman IL, Yokoyama WM. In vivo natural killer cell activities revealed by natural killer cell-deficient mice. Proc Natl Acad Sci U S A 2000;97:2731-6.

3. Imai K, Matsuyama S, Miyake S, Suga K, Nakachi K. Natural cytotoxic activity of peripheral-blood lymphocytes and cancer incidence: an 11-year follow-up study of a general population. Lancet 2000;356:1795-9.

4. Jobin G, Rodriguez-Suarez R, Betito K. Association between natural killer cell activity and colorectal cancer in highrisk subjects undergoing colonoscopy. Gastroenterology 2017; 153:980-7.

5. Lee J, Park KH, Ryu JH, Bae HJ, Choi A, Lee H, et al. Natural killer cell activity for IFN-gamma production as a supportive diagnostic marker for gastric cancer. Oncotarget 2017;8:7043140.

6. Barkin J, Rodriguez-Suarez R, Betito K. Association between natural killer cell activity and prostate cancer: a pilot study. Can J Urol 2017;24:8708-13.

7. Ordóñez-Mena JM, Schöttker B, Mons U, Jenab M, Freisling $\mathrm{H}$, Bueno-de-Mesquita B, et al. Quantification of the smokingassociated cancer risk with rate advancement periods: metaanalysis of individual participant data from cohorts of the CHANCES consortium. BMC Med 2016;14:62.

8. Lu LM, Zavitz CC, Chen B, Kianpour S, Wan Y, Stämpfli MR. Cigarette smoke impairs NK cell-dependent tumor immune surveillance. J Immunol 2007;178:936-43.

9. Ferson M, Edwards A, Lind A, Milton GW, Hersey P. Low natural killer-cell activity and immunoglobulin levels associated with smoking in human subjects. Int J Cancer 1979;23:603-9.

10. Phillips B, Marshall ME, Brown S, Thompson JS. Effect of smoking on human natural killer cell activity. Cancer 1985;56:2789-92.

11. Takeuchi M, Nagai S, Izumi T. Effect of smoking on natural killer cell activity in the lung. Chest 1988;94:688-93.

12. Kusaka $\mathrm{Y}$, Kondou $\mathrm{H}$, Morimoto $\mathrm{K}$. Healthy lifestyles are associated with higher natural killer cell activity. Prev Med 1992;21:602-15.

13. Inoue C, Takeshita T, Kondo H, Morimoto K. Healthy lifestyles are associated with higher lymphokine-activated killer cell activity. Prev Med 1996;25:717-24.

14. Morimoto K, Takeshita T, Inoue-Sakurai C, Maruyama S. Lifestyles and mental health status are associated with natural killer cell and lymphokine-activated killer cell activities. Sci Total Environ 2001;270:3-11.

15. O'Shea D, Cawood TJ, O'Farrelly C, Lynch L. Natural killer cells in obesity: impaired function and increased susceptibility to the effects of cigarette smoke. PLoS One 2010;5:e8660.

16. Valiathan R, Lewis JE, Melillo AB, Leonard S, Ali KH, Asthana D. Evaluation of a flow cytometry-based assay for natural killer cell activity in clinical settings. Scand J Immunol 2012;75:455-62.

17. Lee SB, Cha J, Kim IK, Yoon JC, Lee HJ, Park SW, et al. A highthroughput assay of NK cell activity in whole blood and its clinical application. Biochem Biophys Res Commun 2014;445:584-90. 
18. Rodu B, Cole P. Smoking prevalence: a comparison of two American surveys. Public Health 2009;123:598-601.

19. WHO Expert Consultation. Appropriate body-mass index for Asian populations and its implications for policy and intervention strategies. Lancet 2004;363:157-63.

20. SRNT Subcommittee on Biochemical Verification. Biochemical verification of tobacco use and cessation. Nicotine Tob Res 2002;4:149-59.

21. Hamaguchi M, Kojima T, Itoh Y, Harano Y, Fujii K, Nakajima T, et al. The severity of ultrasonographic findings in nonalcoholic fatty liver disease reflects the metabolic syndrome and visceral fat accumulation. Am J Gastroenterol 2007;102:2708-15.

22. Sopori ML, Gairola CC, DeLucia AJ, Bryant LR, Cherian S. Immune responsiveness of monkeys exposed chronically to cigarette smoke. Clin Immunol Immunopathol 1985;36:338-44.

23. Nakachi K, Imai K. Environmental and physiological influences on human natural killer cell activity in relation to good health practices. Jpn J Cancer Res 1992;83:798-805.
24. Alter G, Malenfant JM, Altfeld M. CD107a as a functional marker for the identification of natural killer cell activity. J Immunol Methods 2004;294:15-22.

25. Claus M, Greil J, Watzl C. Comprehensive analysis of NK cell function in whole blood samples. J Immunol Methods 2009;341:154-64.

26. Chakraborty A, Chakraborty NG, Chattopadhyay U. Age related natural killer activity of peripheral blood lymphocytes from healthy subjects and cancer patients. A comparative in vitro study with interleukin-2. Tumori 1994;80:233-7.

27. Lee DH, Kim M, Kim M, Lee YJ, Yoo HJ, Lee SH, et al. Agedependent alterations in serum cytokines, peripheral blood mononuclear cell cytokine production, natural killer cell activity, and prostaglandin F2a. Immunol Res 2017;65:1009-16.

28. Hu C, Scorza Smeraldi R, Radelli L, Fabio G, Vanoli M, Zanussi C. Age- and sex-dependent changes in natural killer cell activity. Boll Ist Sieroter Milan 1987;66:289-96. 